\title{
Cult Centralization in Deuteronomy 12: \\ Between Deuteronomistic History and Pentateuch
}

\author{
THOMAS CHRISTIAN RöMER
}

\section{Introduction}

The present discussion on the Pentateuch and on the so-called Deuteronomistic History (DH) looks like a battlefield. In particular, the recent and scathing contestations of the existence of a DH have again raised the issue of the very nature of Deuteronomy.

If there is no organic bond between the last book of the Pentateuch and the first part of the Former Prophets, Deuteronomy should be interpreted exclusively as the conclusion of the Pentateuch, and not as the overture to the Former Prophets, as the Dtr History hypothesis would have it. However, anyone reading Deuteronomy carefully will soon notice how numerous texts prepare the reader for what follows. Thus, the Promised Land is very often referred to in the book of Deuteronomy as the "land you will enter when crossing the Jordan". Does such a formula mean anything without the narrative in Jos 3-4? Of course, the opponents of the DH hypothesis may object to this observation by arguing for the existence of an Hexateuch à la Wellhausen. But this suggestion would not solve the problem. Several other texts in Deuteronomy prepare their reader/listener for events reported later in Judges ${ }^{\prime}$ or in Kings. This is notably the case for the motif of sanctuary centralization, which relates Deuteronomy to recurring concerns in the Books of Kings. In contrast to the Patriarchal rarratives or to the Covenant Code, which do not seem really to be concerned with the issue of an unique sanctuary, the loyalty of the successive kings to the Temple of Jerusalem is a leitmotif and major issue in Kings. The insistence on YHWH's one legitimate temple could nevertheless seem

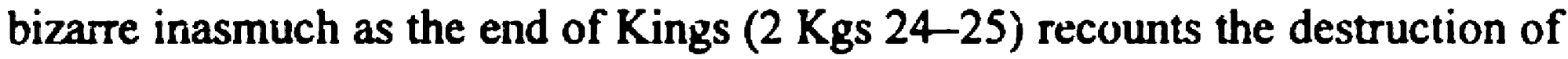
that very temple. And yet it is precisely that tension which, to my mind, offers strong support to the existence of a Deuteronomistic History, even if this "history" should differ considerably from that of Noth's original theory.

$1 \mathrm{Cf}$. the exhortations in Dtn 6,12ff and the corresponding transgressions in Jdg $2,12 \mathrm{ff}$, or the curses in Dtn 28 and their fulfillment in $2 \mathrm{Kgs} 17$ and $2 \mathrm{Kgs} 25$. 


\section{Deuteronomy 12: A program with multiple aims}

The Deuteronomic code opens with a text that insists several times on the fact that YHWH has chosen for himself only one place "to put his Name there" (vv. 4-7.11-12.13-14.26-27). If we start from this fourfold insistence on the uniqueness of the place chosen by $\mathrm{YHWH}_{\mathrm{H}}$, we may notice how the first three statements are at the center of three sequences, which are all structured the same way. Namely, in these three cases the main commandment is preceded by a negative statement: vv.2-4 (4) - not to act towards YHWH in the way of the nations; vv. 8-10 (8) - not to act as today; v. 13-not to offer holocausts in all places. Furthermore, each sequence ends witch a call to joy (vv. 7.12.18) ${ }^{2}$. These observations thus point to three distinct units, delimited as follows: vv. $2-7 / 8-12 / 13-18\left(19^{3}\right)$. The first unit is manifestly linked with vv. 29-31, whereas vv. 13-18 are taken up in 20-28. Such delimitation, which joins a remarkable scholarly consensus ${ }^{4}$, allows for the identification of at least three periods or three different theologies of the unique sanctuary.

It is generally acknowledged that within Dtn 12,1-19, vv. 13-18 constitute the kernel to which first vv. 8-12, then vv. 2-7 were added. This redactional process corresponds to a kind of inverted Fortschreibung, which may be compared to the modern practice of successively prefacing new editions to successful books 5 .

\subsection{Din 12,13-18: Practical consequences of cult centralization}

This prescription begins by opposing the multitude of sacred places ( $k a \dot{l}$ $m \bar{a} q \hat{m}$ ) to the unique sanctuary that YHWH will choose in the territory of only

2 Cf. R. Smend: Die Entstehung des Alten Testaments, Stuttgart et al. 1978, 72-73.

3 The concern for the Levite in $v .19$ may stem from a late redaction close to the ideology of Chronicles, cf. U. Dahmen: Leviten und Priester im Deuteronomium. Literakritische und redaktionsgeschichtliche Studien, BBB 110, Bodenheim 1996, 379.

4 See among recent studies E. Reuter: Kultzentralisation. Entstehung und Theologie von Dtn 12, BBB 87, Frankfurt a.M. 1993, 100-114; E. Nielsen: Deuteronomium, HAT 1/6, Tubingen 1995, 135-136; M. Keller: Untersuchungen zur deuteronomisch-deuteronomistischen Namenstheologie, BBB 105, Weinheim 1996, 25-44; B.M. Levinson: Deuteronomy and the Hermeneutics of Legal Innovation, New York/ Oxford 1997, 21-28.

5 The sequence: $12,12-18 / 12,8-12 / 12,2-7$ is corroborated by the evolution of the centralization formula:

v. 14: The place (māqbm) that YHWH will choose in one ('ahadd) of your tribes;

v. 11: The place (māqóm) that YHWH, your God, will choose as a dwelling (šakkēn) for his name;

v. 5: The place (māqôm) that YHWH, your God, will choose out of all your tribes as his habitation $(\zeta k n)$ to put his name there.

V. 5 obviously combines v. 14 and v. 11 . 
one tribe. This precision ${ }^{6}$ makes it difficult to read the centralization formula in a distributive manner, so as to understand that at each period God would choose for himself another sanctuary. Thus, the māqôm in Dtn 12 does not point at anything other than the Temple of Jerusalem, and the "one" tribe cannot mean any other than (the kingdom of) Judah". The same ideology is to be found in Ps 78, which is generally identified as Dtr ${ }^{8}$, and where YHWH explicitly refuses to choose Ephraim (the North) but chooses instead "the tribe of Judah, the mountain of Zion which he loves" (v. 68). The author of Dtn 12,13ff. thus takes up the tradition of Zion's election and harmonizes it with the Dtr ideology by transforming it into an exclusive election, incompatible with any other sanctuary.

The social-historical context of Dtn $12,13-18$ is most probably that of the measures of administrative centralization of the kingdom of Judah under the reign of Josiah. Even if it remains difficult, if not highly hazardous, to attempt any historical reconstruction of the so-called "Josianic reform", it seems nevertheless quite clear that the first version of Deuteronomy must have originated in that context, or if one prefers to remain vague: in the context of the Assyrian Empire of the seventh century BCE'.

If one agrees that the extent of the Josianic Deuteronomy corresponded to the original kernel of Dtn 12-26, introduced by the beginning of the Shema Yisra' $e l$ (Dtn 6,4-5) and concluding with a first version of the set of blessings and curses found in Dtn 28*, it appears then that Dtn 6,4-5 and 12,13-14 are linked together and coherently organized:

"Hear o Israel, YHWH is our God, YHWH is ONE ('ahād). You shall love YHWH your God with all $\left(b^{2}-k a l\right)$ your heart, with all $\left(b^{2}-k \dot{a} l\right)$ your soul, and with all ( $\left.b^{2}-k \dot{a} l\right)$ your might. Take care that you do not offer your burnt-offerings at any $\left(b^{2}-k \dot{a} l\right)$ place you happen to see. But only at the place that YHWH will choose in ONE ('ahe $\bar{a} d$ ) of your tribes - there you shall offer your burnt-offering and there you shall do everything ( $k a l l$ I command you".

This passage is organized by way of the dialectical opposition between kal (five times) and 'ahàd (twice). To the one God corresponds the election of a unique sanctuary in one tribe alone, together with the rejection of all other holy places and all other tribes (i.e., the Northern kingdom). There is nowhere here any allusion to the literary fiction of Deuteronomy in its final form. The pas-

6 Against M. Rose: 5. Mose, ZB.AT 5, Zurich 1994, 12, and others, it is unnecessary to consider this relative clause as a later addition.

7 A.D.H. Mayes: Deuteronomy, NCBC, Grand Rapids/ London 1981, 227; Reuter: Kultzentralisation, 121.

8 The psalm is variously dated: from Josiah's time up to the Persian period. See the discussion in B. Weber: Psalm 78: Geschichte mit Geschichten deuten, ThZ 56 (1978) 194-214.

9 One major argument is the fact that the author of Din 28 copies the curses of Essarhaddon's treaty (about 672 BCE). See on this H.U. Steymans: Deuteronomium 28 und die adê zur Thronfolgeregelung Asarhaddons. Segen und Fluch im Alten Orient und in Israei, OBO 145, Fribourg/ Gortingen 1995. 
sage is addressed to free, rather wealthy citizens (they own slaves), who are settled in their townships (v. 18).

The question remains as to the link between $12,13-18$ and 12,20-28. 12,2028 takes up again the main issue of vv. 13-18, the legislation on profane slaughter, and restricts it to cases in which "the place where YHWH your God will choose to put his name is too distant from you" (v. 21). Some scholars assume that vv. $20 \mathrm{ff}$. stem from the same author as vv. 13-1810; others situate them a little later, towards the end of Josiah's reign, understanding v. 20 as an allusion to Josiah's expansion policy as related in Kings ${ }^{\prime \prime}$. This last point is far from being assured: historically speaking, the actual expansion of Judah under Josiah was most likely quite modest ${ }^{12}$. Moreover, the narrative of $2 \mathrm{Kgs} \mathrm{23,15-20}$ never takes up the terminology of Dtn 12,2013. The use of $g^{2} b u \hat{~}$ in Dtn 12,20 28 (cf. also Dtn 19,8, a text of late origin) can hardly refer to the Promised Land, which in the Dtr tradition is called 'ădāmā or 'äras. Dtn 12,20-28 might be connected to the promotion of the ideology of a "Davidic-Solomonic Empire" (as in $1 \mathrm{Kgs} \mathrm{5,1-5);} \mathrm{however,} \mathrm{the} \mathrm{best} \mathrm{hypothesis} \mathrm{may} \mathrm{be} \mathrm{to} \mathrm{see} \mathrm{it} \mathrm{as} \mathrm{an} \mathrm{allusion}$ to the situation of the diaspora in post-exilic times: the Temple is rebuilt, but the Jews in Babylon or in Egypt cannot go there each time they slaughter ${ }^{14}$. According to A. Rofé, Dtn 12,20-28 is meant to harmonize the Dtr law of centralization with the legislation of Lev $17^{15}$, which seems less concerned with the idea of centralization than with the condemnation of profane slaughter. If this is the case, Dtn 12,20ff presupposes the post-exilic Holiness Code, and is still later ${ }^{16}$.

These two passages dealing with the practical consequences of cultic centralization presuppose the existence of the Temple: in 12,13ff., the first Temple, in $12,20 \mathrm{ff}$, the second Temple. This is not the case with Dtn 12,8-12, where the

10 For instance E. Otto: Vom Rechtsbruch zur Sunde. Priesterliche Interpretationen des Rechts, JBTh 9 (1994) 25-52; 35.

11 For instance Keller: Untersuchungen, 37.

12 Cf. Reuter: Kultzentralisation, 92.

13 Levinson: Hermeneutics, 39-40. Also, we might ask with J. Van Seters: The Deuteronomistic History: Can It Avoid Death By Redaction?, in: T. Römer (ed.), The Future of the Deuteronomistic History, BEThL 147, Leuven, 2000, 213-222, if this story is not entirely fictitious.

14 See also Num 9,10-14, which reflects the same concern, this time in relationship to the celebration of Passover in the Persian period: the case is made that somebody might travel and, being far away, be unable to accomplish the ritual, and a specific legislation is then promoted in order to answer the case.

I5 A. Rofé: Introduction to Deuteronomy: Part I and Further Chapters (Ivrit), Jerusalem $1988,16$.

16 Reuter: Kultzentralisation, 106, wants to locate Dtn 12,20ff during the period of the monarchy, arguing that the passage can only be understood if the Temple still exists; but she never imagines that the temple in question could also be the second Temple. The late date of $12,20 \mathrm{ff}$ is further supported by the fact that in v. 21 , the centralization formula appears in a form which corresponds to its most recent formulation. 
original prescription is now brought up to date in order to fit a new historical context.

\subsection{Din 12,8-12: Cult centralization in the absence of the Temple}

The addressees of this instruction are manifestly the exiles. They are identified as the generation of the desert to whom (re)entrance into the land is promised. Here the literary fiction of Deuteronomy as Moses' testament becomes for the first time transparent, since v. 10 evokes the coming crossing of the Jordan. The beginning of the text constructs an opposition between "today" (where everyone does "what is right in his own eyes", cf. Jdg 17,6;21,25) and the entrance into the promised - but not yet fulfilled - "rest" (v. 9). What does this term, $m^{2}$ nûh $\bar{a}$, mean? In a number of texts (Is 66,$1 ;$ Ps 95,$11 ; 132,8.14$ ), the word refers to the Jerusalem Temple. More important still, however, Dtn 12,9

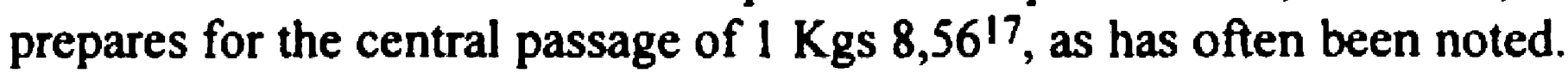

Dtn 12,9: "You have not yet come into the rest and the possession that YHWH your God is giving to you". - $1 \mathrm{Kgs} \mathrm{8,56:} \mathrm{"Blessed} \mathrm{be} \mathrm{YHWH} \mathrm{who} \mathrm{has}$ given rest to the people Israel according to all ... that he spoke through his servant Moses".

Only in these two texts do we read that YHWH gives a $m^{2}$ nûhā to Israel; this implies a very clear connection. The link between Dtn 12,9ff. and Kings is further reinforced by the fact that the last occurrence of the verb "to live securely" $(12,10)$ in the historical books is found precisely in $1 \mathrm{Kgs} 5,5$ ("During Solomon's lifetime Judah and Israel lived in security ..."). These intertextual relations between Dtn 12,9-10 and $1 \mathrm{Kgs} \mathrm{5-818}$ strongly support the existence of a $\mathrm{DH}$, as we will see further below. At the same time, however, they also exemplify a will to create a periodization of history: promises made to the addressees of Deuteronomy did not come to complete fulfillment until the building of the Temple under Solomon. Indeed, although Joshua already achieves rest from his enemies by the end of the conquest (Jos 21,43-45), as in Dtn 12,10, it is only with the building of the Temple that the motif of the gift of the land finds its accomplishment. This is made possible by the fact that in the Dtr literature, the term màqôm may designate not only the place of the Temple, but also the entire land, in the center of which the unique sanctuary of YHWH will stand. Since in Dtn 12,9, the author draws a parallel between $m^{2} n u \hat{h} \bar{a}$ and nahälä, the term mäqôm mentioned in 12,11 may well have the same meaning.

If Dtn 12,8-12 is the opening of the exilic edition of the Dtr Code, it is remarkable that the same ambiguity about the place shows up again in the finale

17 G. Braulik: Zur deuteronomistischen Konzeption von Freiheit und Frieden, in: J.A. Emerton (ed.), Congress Volume. Salamanca 1983, VTS 36, Leiden 1985, 29-39; 30; B. Gosse: La rédaction deutéronomiste de Deutéronome 12,10 à 1 Rois 5,18 et la tranquillité devant les ennemis d'alentour, Eglise et Theologie 25 (1994) 323-331; 331.

18 Gosse: Rédaction deutéronomiste, 330. 
of the Code. In Dtn 26,3, namely, the same centralization formula appears as in 12,11 ("the māqôm that YHWH will choose for his name to dwell in it"); then the following historical creed in vv. 5-9 ends with this statement: "(YHWH) made us enter this māqôm, he gave us this land").

In these texts from the exilic edition of Deuteronomy, temple and land are intrinsically bound together. For the author of Dtn 12,8ff., restoring the temple and its sacrificial worship cannot be separated from restoring YHWH's people to its country. Does this imply that there can be no worship of YHWH without the Temple? Dtn 12,8-12 does not clearly answer this question. However, a close look detects a clue in the broadening of the centralization formula: YHWH will choose the place where to make his name dwell. This is a probable recurrence of the Akkadian šakanu šumšu which designates the taking over and juridical claim of a place ${ }^{19}$. In the context of (exilic) Dtr theology, the formula implies a certain "secularization" 20 " of the Temple: YHWH himself does not dwell in the Temple but in the sky (cf. also Dtn 26,15 and $1 \mathrm{Kgs} \mathrm{8}$ ). Although he may have his name dwell in the Temple, which means that his presence may be experienced by his people through worship, this divine presence no longer depends on the Temple itself 21 . The question is thus raised anew: in what does the foundation of Israel's identity as YHWH's people reside, if not in the temple? This is the question which the author of Dtn 12,2-7 tries to answer.

\subsection{Din 12,2-7: Cult centralization and the rejection of "illegitimate" cults}

VV. 2-7, which open the centralization law in its present form, give to the legislation a specifically aggressive tone. The theme of the unique sanctuary becomes mainly a pretext for developing a theology of strict separation from the "nations" dwelling in the land. A comparable ideology is to be found in Din 7,1-6.22-26 and 9,1-6. Scholars from the "Göttingen School" often attribute these texts to "DtrN", which is to be dated around the end of the Exile or, more likely, at the beginning of the Persian period 22 . Vocabulary and content indeed corroborate this dating. Thus, the idiom "to seek YHWH" (v. 5) is typical of the Book of Chronicles; the words trûmā ("appropriation") and ma'ăśér (tithe, dime), which appear as a pair in Dtn 12,6, are not attested together elsewhere except for Neh 12,44 and Mal 3,8, two texts from the Persian period.

19 F. García López: Le Deutéronome, CEv 63, Paris 1988, 32. See now S.L. Richter: The Deuteronomistic History and the Name Theology. Lešakhen šemo šam in the Bible and the Ancient Near East, BZAW 318, Berlin/ New York 2002.

20 T.N.D. Mettinger: The Dethronement of Sabaoth: Studies in the Shem and Kabod Theologies, CB.OT 18, Stockhom 1982, 36-37.

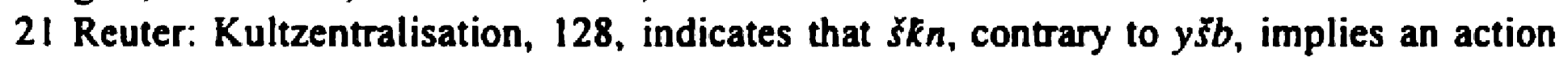
which is limited in time.

$22 \mathrm{Cf}$. recently Keller: Untersuchungen, 40-42, as well as J. Pakkala: Intolerant Monolatry in the Deuteronomistic History, Publications of the Finnish Exegetical Society 76, Helsinki/ Gottingen 1999, 94-99. 
Furthermore, the ideology conveyed by Dtn $12,4 \mathrm{ff}$. is close to that of the books of Ezra-Nehemiah. "The nations from which one must separate oneself" designate either the Babylonian or Persian multicultural and ethnically mixed society, or the so-called "people of the land", that is the non-exiled population of Judah, whom the representatives of the Babylonian Golah understood as not belonging to the "true Israel" (cf. Ezr 9,1-3; Neh 9,2;1323). The population that had remained in Judea was probably more "conservative" in its religious practices than the deported intelligentsia. Texts such as Ez 8 (a vision of polytheistic cults in the Temple of Jerusalem) or Jer 44,15-19 (libations for the "Queen of heaven") bear witness to a continuing popular religiosity. This explains the ideological and very harsh tone of Dtn 12,2ff.

On the one hand, Dtn 12,2-7 contrasts the places where the "nations" worship to the one place chosen by YHWH; on the other hand, the "name" of the nations (v. 3) is set over against the name of YHWH (v. 5). The issue at stake here is no longer the multiplicity of Yahwistic sanctuaries (as opposed to the only legitimate one), as in Dtn 12,13ff., nor the traditional connection between possession of the land and worship in the Temple, as in Dtn 12,8ff. For now, it is YHWH, the God of Israel, who is set over against the gods of the gojyim $(12,2)$. The theme of the one sanctuary is used to affirm YHWH's uniqueness against traditional, ongoing polytheism. Dtn 12,2-7 and 12,29-31 (both sequences are generally attributed to the same redactor ${ }^{24}$ ) are composed in accordance with the literary fiction of Deuteronomy. They are addressed to an audience that has the possibility to return into the land. With the use of verbs such as "to demolish", "to break", "to bum", Dtn 12,2 also alludes to cultic reforms as related in Kings, especially those of Josiah"25. But the issue here is no longer the "cleansing" of the Temple, but rather the purification of the addressees from their polytheism.

To sum up briefly our investigation on Dtn 12: the three main layers identifiable in this text are differently concerned with the problem of cult centralization. The topics brought forward are not so much topics characteristic of the

23 These texts are primarily concerned with the prohibition of mixed marriages, as in Dtn 7.

24 See for instance $\mathrm{N}$. Lohfink: Fortschreibung? Zur Technik von Rechtsrevisionen im deuteronomistischen Bereich, erortert an Deuteronomium 12, Ex 21,2-11 und Dtn 15,12-18, in: T. Veijola (ed.), Das Deuteronomium und seine Querbeziehungen, Schriften der Finnischen Exegetischen Gesellschaft 62, Helsinki/ Gottingen 1996, 127-171;137. Levinson: Hermeneutics, 25-26, notices that vv. 29-31 do not mention cult centralization, and ascribes them therefore to a later redactor. Another difference between 12,2ff and 12,29ff may be emphasized: according to $\mathrm{vv}$. $2 \mathrm{ff}$, the Israelites are going to drive out the nations, whereas according to vv. 29ff, this is done by YHWH. However, the same phenomenon can be observed in Dtn 7,16.21-26, and in 9,1-6; thus, there is no need to postulate another Dtr layer. The current inflation of Dtr redactors is already sizeable enough.

25 H.-D. Hoffmann: Reform und Reformen. Untersuchungen zu einem Grundthema der deuteronomistischen Geschichtsschreibung, AThANT 66, Zurich 1980, 342-346. 
Tetrateuch, but key themes of the DH. In a certain way, the three Dtr layers in Dtn 12 thus lay the groundwork for the three distinct layers discernable in 1 Kgs 8, as we will now demonstrate.

\section{From the dedication of the Temple to its destruction (1 Kings 8)}

In the framework of the $\mathrm{DH}$, the narrative of the building of the temple (1 Kgs $6-7)^{26}$ and of its dedication by Solomon (1 Kgs 8) holds a central position. The report of the dedication itself is dominated by a grand prayer. At the level of the narrated story, the building of the temple corresponds to the fulfillment of all divine promises: At the level of the audience, however, two distinct historical contexts seem to be addressed: the situation of the exile, when the Temple whose construction has just been related in the previous chapters stands in ruins; and the context of the return and the restoration.

In its final form, $1 \mathrm{Kgs} 8$ offers a finely worked structure.

VV. 1-2: Introduction: Assembling the people

VV. 3-13: Setting of the Ark and sacrifices

VV. 14-61: THREE SPEECHES BY SOLOMON

VV. 14-21: Facing the assembly: blessing

VV. 22-53: Facing the altar: prayer

VV. 54-61: Facing the assembly: blessing

VV. 62-65: Sacrifices

V. 66: Conclusion: Sending back the people back

The text clearly places at its center Solomon's prayer to YHWH. Despite the structure, however, it is quite clear that $1 \mathrm{Kgs} 8$ was not written by one single author. Even if there is a debate about the chapter's diachrony, we may grosso modo distinguish among a traditional (pre-Dtr) kernel in vv. $1-13^{* 27}$, a Josianic edition and two exilic or even post-exilic Dtr editions, plus a late reworking in the Priestly style from the Second Temple period. From a diachronic perspective, the successive stages in the redaction of the text correspond more or less to the synchronic succession of the sequences in vv. 14-21.22-53.54

$26 \mathrm{~J}$. Van Seters: Solomon's Temple: Fact and Ideology in Biblical and Near Eastern Historiography, CBQ 59 (1997) 45-57.

27 We cannot discuss here the problem raised by vv. 12-13, which state that YHWH desires to dwell in the darkness. The LXX quotes this poem at another place (after 8,53); $1 \mathrm{Kgs} \mathrm{8,12-}$ 13 may thus well be a fragment from an older text. The mention of the darkness probably alludes to the clouds in which the weather-God YHWH hides himself. If this is correct, the old story was probably about the coming of the weather-God YHWH to inhabit the Jerusalem Temple. It is clear in any case that the original kemel of vv. 1-13 was considerably reworked by Priestly redactors (cf. vv. 10-11 and Exod. 40,34f [P]); see on this E. Wurthwein: Die Bucher der Konige. I Konige 1-16, ATD 11/1, Gottingen 1977, 84-91. 
$61.62-64$, each new redactor expanding the text of the previous ones. At the same time, it is apparent that each section cannot be attributed to a single redactor, and that each further redactor probably also edited the already existing text.

\subsection{Kings 8,14-21: Temple and Davidic dynasty}

This unit draws a parallel between the divine election of David and his dynasty, and the election of the Temple (cf. v. 16 and the parallel in 2 Chron 5,5-6) 28 . Thus it posits an indissoluble bond between the Davidic dynasty and the Temple of Jerusalem ${ }^{29}$. This observation favors an attribution of vv. $14 \mathrm{ff}$. to a Josianic edition of the Book of Kings. The same results from the fact that the emphasis placed upon the divine choice operated "among the tribes" clearly recalls the formulation of Dtn 12,14, which belongs to the Josianic layer of Dtn 12 as we have seen above. The triumphant tone of $1 \mathrm{Kgs} 8,14-21^{*}$ regarding the king and the Temple is however altered in the central prayer that follows.

\subsection{Kings 8,22-53 and YHWH's withdrawal from the Temple}

The first part of this long sequence (vv. 22-26) offers a transition from the preceding verses. There is still mention of the "father David" - who does not occur again -, but v. 26 now makes the promise of an eternal dynasty conditional, "a typical Dtr concept reflecting the situation after 587" according to Würthwein $^{30}$. The same can be said about vv. 27-30, which introduce the presentation of the seven occasions for prayer in vv. $31 \mathrm{ff}$.

Significantly enough, two important transformations take place in these verses regarding the Temple. The first is found in v. 27, where Solomon acknowledges: "May God really dwell on earth? The heavens and the heavens of heavens cannot contain you. And much less the House I built for you". In flagrant contrast to the importance given to the building of the temple in the first part of the Solomonic speech, this verse highlights the absolute transcendence of YHWH. This does in no way downplay the importance of the Temple, but it makes now possible to worship YHWH outside the Temple.

When analyzing the exilic layer of Dtn 12 , we noted how the redactors of $\mathrm{vv}$. $8 \mathrm{ff}$. had indissolubly connected the gift of the land to the election of the

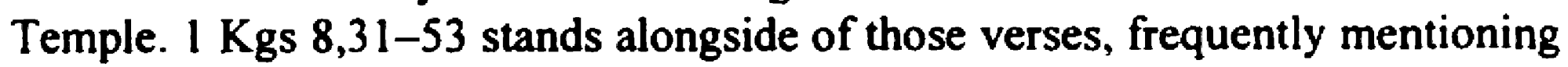

28 The MT of $1 \mathrm{Kgs} 8$ does not mention the election of Jerusalem, in contrast to Chronicles. Either Chronicles wants to correct a difficult text, or the MT in $1 \mathrm{Kgs} \mathrm{8,16}$ was corrupted by a scribal error (homoioarchton). According to A.G. Auld: Kings Without Privilege: David and Moses in the Story of the Bibles Kings, Edinburgh 1994, 59, the text in Chronicles reflects the original version. For the relationship between $1 \mathrm{Kgs} 8$ and $2 \mathrm{Chr} 6$, cf. W. Johnstone: Solomon's Prayer: Is Intentionalism Such a Fallacy?, STh 47, 1993, 119-133.

29 This is another parallel with the Deuteronomic code: besides the place (especially in Dtn 12 and 16), it is the king $(17,15)$ who is chosen by YHWH.

30 Wurthwein, Konige, 97. 
the land, which is characterized three times as having been given to the fathers (vv. 30.40.48). This is another element that argues for the existence of a coherent Dtr redaction linking together the books of Deuteronomy to Kings. In Deuteronomy and Joshua, the motif of the land promised to the fathers occurs very often. It appears for the last time in Jos $21,43-45$, in a passage in which Joshua states that all the divine promises have been fulfilled. After the book of Joshua, the oath formula will be replaced by the motif of the land given to the fathers $^{31}$. Now, the first time this motif appears is precisely in $1 \mathrm{Kgs} 8$. This means that in the mind of the Deuteronomists, the land is not entirely given until the temple is built ${ }^{32}$.

Going back to the structure of vv. 31-53, one may further observe that every description of the various occasions for prayer mentions the same basic elements: the situation, the localization of the person praying, the appeal to God asking him to listen, and the divine intervention as required in the prayer.

Among these elements, the most stable formulation is found in the call to listen: on each occasion, we find the same idiom, "listen from heaven", sometimes with a specification added: "the place where you dwell". As against this call to God, which remains always identical, there is an evolution as to the place of prayer. In the first case mentioned, the place is clearly located in the Temple, "before your altar, in this house" (v. 31). Then (from the third case onwards), prayer goes in the direction of the house/ place. YHWH's withdrawal becomes reinforced by the end when praying individuals are set in another country; their prayer is then addressed towards the land of the fathers, the city and the house (vv. 46-51). Thus, beginning with its very dedication the Temple's function is defined as determining the direction of the prayers of the distant community, very much like the qibla in Islamic tradition. While insisting on the importance of the Temple, the exilic Dtr authors build up new patterns for the worship of YHWH in trying to respond to the situation of exile and diaspora.

\subsection{Kings 8,54-61 and the disappearance of the Temple}

While there is a strategy of divine withdrawal at work in the central prayer, the Temple tends to disappear altogether in the last blessing by Solomon, after a last allusion in v. 5633. In a sense, laws and ordinances (v. 58 and 61 ) now replace Temple and land. This sequence also insists on the opposition between Israel, YHWH's people, and other peoples (vv. 59.60, cf. also v. 53). This ob-

31 For more details see T. Romer: Deuteronomy in Search of Origins, in: G.N. Knoppers/ J.G. McConville (eds), Reconsidering Israel and Judah. Recent Studies on the Deuteronomistic History, SBTS 8, Winona Lake 2000, 112-138; 126-135.

32 The same link between the gift of the land to the fathers and the Temple occurs in Jer. 7. cf. T. Romer: How Did Jeremiah Become a Convert to Deuteronomistic Ideology?, in: S.L. McKenzie/ L.S. Schaering (ed.s), Those Elusive Deuteronomists, JSOT.S 268, Sheffield 1999, 189-199; 194.

33 Apparently, v. 56 and vv. 57 ff do not belong to the same Dtr layer. 
servation connects these verses to the late Dtr strata of Dtn 12,2ff.: Israel's identity is not primarily expressed in terms of the Temple, but by its election and its obedience to the Torah, which suffice to define Israel's distinctiveness from the other nations.

\subsection{Kings 8,62-64 and Priestly elaborations on the sacrificial cult}

The ultimate episode, reported in vv. 62-64, which concludes the inauguration of the Temple, clashes with the content of the Solomonic prayer. It deals with an incredible quantity of animals sacrificed ( 22000 heads of cattle and 1200000 heads of small cattle, v. 63). This description, with its fantastic numbers ${ }^{34}$, thereby changes the whole precinct of the Temple into a gigantic place of sacrificial slaughter. This text is definitely not from the hand of Dtr. It must come from a priestly milieu close to Chronicles ${ }^{35}$, which cannot conceive of YHWH's cult as being other than sacrificial, and reacts critically to the evolution traceable in the previous redactional stages

To sum up: The different strata identified in $1 \mathrm{Kgs} 8$ extend from the time of the First to the Second Temple. The three Dtr layers are closely connected to those already manifest in Dtn 12 . This means at least that the two texts were systematically composed in relation to each other. Dtn 12 clearly opens a theological pattern which is then resumed in Kings, and which definitely characterizes the $\mathrm{DH}$ as a distinct literary collection. This becomes all the more evident when we observe that the Tetrateuch evidences a very different cultic concern; and we will briefly address this last issue by way of conclusion.

\section{The Tetrateuch and cult centralization}

It is commonly held that the Dtr and the Priestly school share the idea of one legitimate sanctuary. It seems quite clear, however, that the priestly writers must have had a more open understanding of this doctrine, possibly accepting a diversity of cultic places. Thus, one may ask whether the building of the mobile sanctuary at Mt Sinai in Ex $25 \mathrm{ff}$. cannot be understood as reflecting a willingness to accept Yahwistic sanctuaries elsetvhere than in Jerusalem, for instance Bethel or Samaria ${ }^{36}$. Be that as it may, certain texts of the Tetrateuch (but also

34 Assuming that these sacrifices took place during all seven days, and that they were offered 24 hours a day, there would have been 130 head of large cartle and 714 head of small cattle sacrificed per hour.

35 Wurthwein: Könige, 101-102; P. Buis, Le livre des Rois, SB, Paris 1997, 88.

36 B.J. Diebner, Gottes Welt, Moses Zelt und das salomonische Heiligtum. Anmerkungen zur Vollendung des Tempels, in: T. Römer (ed.), Lectio difficilior probabilior? L'exégèse comme expérience de décloisonnement. Mélanges offerts à Françoise Smyth-Florentin, B.DBAT 12, Heidelberg 1991, 127-154; J. Blenkinsopp: The Judaean Priesthood during the Neo-Babylonian and Achaemenid Period, CBQ 60 (1998) 25-43. 
some texts in Samuel and Kings ${ }^{37}$ ) assume the existence of several Yahwistic sanctuaries, and this without apparent criticism. The traditional solution has been to attribute these texts to the "ancient" sources of the Pentateuch ${ }^{38}$. But in the context of the recent evolution of Pentateuchal criticism, other solutions to this tension may exist. C. Levin, for instance, holds that the "Yahwist" should be dated to the beginning of the Persian period, and regards him as being representative of "popular" religion, thus coming close to Van Seters' view of a Yahwist characterized by a more "liberal" ideology than his Dtr forerunners ${ }^{39}$. The insistence on the various cultic sites from Noah through Sinai, including the numerous altars built by Abraham and Jacob, could then be explained as antiDtr polemics ${ }^{40}$. The recent thesis by $\mathrm{W}$. Oswald goes in the same direction: he attempts to demonstrate that the so-called "Covenant Code" was edited in the Neo-Babylonian period, together with a first version of its present narrative frame (Ex 19-24*), by the civil servants of Gedaliah in Mizpah. The introduction of the code, in Ex 20,24-26, underlines the simplicity of the altar, thus taking into account, according to Oswald, the precarious economic situation of the country and opposing the sophisticated cult of the Temple ${ }^{41}$. Ex 20,24 ("Make an altar of earth for me and sacrifice upon it your burnt offerings and peace offerings, your sheep and goats and your cattle. Wherever I cause my name to be honored, I will come to you and bless you") could then be understood as a critical response to Dtn 12, underlining YHWH's total freedom even with respect to the place where he has to be worshipped ${ }^{42}$. This does not necessarily mean that the Covenant Code is later than the Deuteronomic Code, as Van Seters would have it $^{43}$. Even though it was most likely earlier, it could have been used during and after the exile in order to express an ideology other than that of the Deuteronomists. When the book of Deuteronomy was separated from the Dtr history to become the last book of the Pentateuch, both views came to coexist, even if, from a synchronic perspective, Deuteronomy presents itself as the "orthodox" interpretation of the foregoing Sinai pericope ${ }^{44}$.

37 For instance I Sam 1,3; 7,17; 16; 1 Kgs 3,4.

38 See still recently Levinson: Hermeneutics, 4.

$39 \mathrm{~J}$. Van Seters: The Theology of the Yahwist. A Preliminary Sketch, in: I. Kottsieper et al. (ed.s), "Wer ist wie du, Herr, unter den Gottern?": Studien zur Theologie und Religionsgeschichte Israels (FS O. Kaiser), Gottingen 1994, 219-230.

40 C. Levin: Der Jahwist, FRLANT 157, Gottingen 1993, 430-432.

41 W. Oswald: Israel am Gottesberg, OBO 159, Fribourg/ Gottingen 1998, 141-143.

42 Levin: Der Jahwist, 431.

43 So J. Van Seters: A Law Book for the Diaspora. Revision in the Study of the Covenant Code, Oxford et al., 2003.

44 At least in the perspective of the Pentateuch. The scribes who wanted to create a Hexateuch had possibly a different conception, since the final cultic actions of Joshua take place in Shechem. This may be understood as an attempt to make the sanctuary of Samaria acceptable. 
One may note, in this context, that at the beginning of the Abraham cycle a compromise is found between the Dtr theology and a more "liberal" one. During his wanderings, Abraham builds altars in Shechem, Bethel (Gen 12,7-8; 13,4) and Mamre-Hebron $(13,8)$, but uses them only "to call upon the name of YHWH"45 (a similar compromise exists in Jos 22). The only place where Abraham actually sacrifices (Gen 22) is the "land of Moriah", which was soon (and possibly by the narrator himself) identified with the Temple of Jerusalem. In this manner, the Abraham story stages the post-exilic scenario of Judaism: liturgical worship anywhere, sacrificial worship at the Temple of Jerusalem exclusively. If this scenario is correct, it implies that the tension between the $\mathrm{DH}$, with its exclusive requirement for cultic centralization, and the priestlyinfluenced Tetrateuch, with its more open perspective on cultic worship, was thus resolved, in later times, by the co-existence of Temple and Synagogue.

45 See on this E. Blum: Die Komposition der Vatergeschichte, WMANT 57, NeukirchenVluyn 1984, 337. 